$\xi=$

\title{
Phylogenetic information of freshwater copepod (Diaptomus sicilis) with special reference to $18 \mathrm{~S}$ rRNA
}

\author{
Gomathi Jeyam Mookkaiah, Ramanibai Ravichandran* \\ Unit of Aquatic Biodiversity, Department of Zoology, University of Madras, Guindy Campus, Tamilnadu, India \\ *Corresponding author E-mail:rramani8@hotmail.com
}

\begin{abstract}
In the present investigation to isolate freshwater calanoid copepods (Diaptomus sicilis) was characterized and identify the organisms by 18S rRNA sequencing. Plankton samples containing D. sicilis were collected during January 2014 (Post-monsoon) from Madippakkam

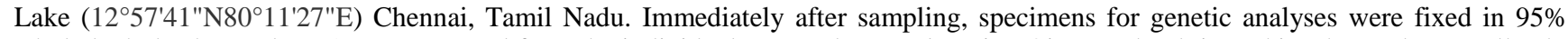
ethyl alcohol. The total DNA was extracted from the individual copepod D. sicilis using Qiagen Blood tissue kit. The nuclear small subunit 18S rRNA gene was amplified using the Universal primer LCO - 1490 (5'-GGTCAACAAATCATAAAGATATTGG-3') and HCO-2198 (5'-TAAACTTCAGGGTGACCAAAAAATCA-3'). PCR products were loaded onto a 1\% TAE agarose gel. Sequences were carried out an automated sequencer. The nucleotide sequence of 1282 base pair region of $18 \mathrm{~S}$ rRNA was determined for D. sicilis. The similarity of sequences of $D$. sicilis was retrieved by BLASTn program and maximum identity and E-value was $76 \%$ and 0.00 , respectively. The PCR products of $D$. sicilis individuals showed $80 \%$ similarity with the partial nuclear small subunit $18 \mathrm{~S}$ rRNA gene region of other calanoid copepods. Based on molecular data the freshwater Calanoid copepods showed different algorithms and similar types of topologies useful for designing molecular analyses using phylogeny tree construction.Present molecular studies on the relationship of D. sicilis with other freshwater calanoid copepods indicate that this species is close to $D$. castor followed by $D$. keniraensis.
\end{abstract}

Keywords: Phylogeny; Diaptomus sicilis; 18 S rRNA; Calanoid; BLAST.

\section{Introduction}

Copepods play a significant role in the food chain of the freshwater ecosystem (Humes 1994). Based on morphological characters, there are 11,500 species of copepods were reported. Copepods well respond to environmental changes and have been recognized as indicators of natural and anthropogenic stress (Hirai et al. 2015). The freshwater diaptomid calanoid Copepods are the most distinct group over 400 species comprised more than 50 genera (Ranga Reddy 1994). In spite of immense taxonomic revision on the basis of detailedminute morphological character, the phylogenetic relationships within and among diaptomid genera remains evasive.In Calanoid copepods, the morphological differences of the male fifth legs play a major role in the classification and identification of species (Ho Young Soh et al. 2012) Molecular taxonomy is an important tool to identify the evolutionary relationship of organisms. Recently, various molecular markers like Internal transcribed spacer (ITS), mitochondrial cytochrome oxidase subunit I (mtCOI) and Restriction fragment length polymorphism [RFLP] has been used to resolve relationships between species and population levels (Sivakumar et al. 2013).

Kanchon et al. (2010) recommended DNA barcoding is a significant and quick method to explore the species its biodiversity assessment. The majority of the researchers used a short section of mitochondrial DNA (mtDNA), the first $\sim 650 \mathrm{bp}$ of the 5' end of the Cytochrome Oxidase. I gene (COI). DNA barcoding has been argued to revolutionize taxonomy allowing rapid species identification without taxonomic expertise at present (Stoeckle et al. 2008). Phylogenetic relationships among calanoid copepods at higher systematic levels (ordinal, familial and generic) have been resolved using the 18S rRNA gene (Bucklin \& Steinke 2011).
Which can be used to examine the evolution of crustacean orders and families. The lower taxonomic level relationships have been resolved using the ITS2 of the nuclear rDNA gene cluster

(Wyngaard et al. 2010).

Combine with mitochondrial genes and nucleic genes would produce more reliable species description than those based on a single gene (Dupuis et al. 2012). One of the candidate nuclear marker is the small nuclear subunit of the ribosomal RNA ( rRNA) gene, which is a common molecular marker frequently used in phylogenetic studies ( Kruger et al. 2012, Petrov et al. 2014, Fonseca et al. 2014). The nuclear 18 S rRNA gene is also favourably used for diversity research in eukaryotes (Tang et al. 2012, Lie et al. 2014 and Zhan et al. 2014). Compared to COI evolution progresses much more slowly in the $18 \mathrm{~S}$ rRNA gene prospectively making, and it's more valuable marker for discriminating between samples at high taxonomic levels (Thum\& Derry 2008). Morphological identification may not effectively capture their inner details (Bucklin 2011). An attempt has been made out of molecular phylogenetic data compared with that of morphological data to clarify copepod Diaptomus sicilis familial relationships of Calanoid.

\section{Materials and methods}

\subsection{Collection and identification of individual}

Plankton samples containing Diaptomus siciliswere collected during January 2014 (Post-monsoon) from Madippakkam Lake $\left(12^{\circ} 57^{\prime} 41^{\prime N} 80^{\circ} 11^{\prime} 27 " E\right)$ Chennai, Tamil Nadu (Fig.1)during the early hours of the day [6-8 am] using $100 \mu \mathrm{m}$ mesh size plankton net at a depth of $40 \mathrm{~cm}$ for 10 minutes. Immediately after sampling, specimens for genetic analyses were fixed in $95 \%$ ethyl 
alcohol; those for morphological examination were fixed in 5\% formalin-lake water solution. Microscopic examinations and dissections were made in Glycerol using Nikon Microscope. Initial drawings were made with camera lucida interference microscopes. The alcohol was changed after $24 \mathrm{~h}$. The specimens were identified to species level using standard keys (Ranga Reddy 1994).

(A)

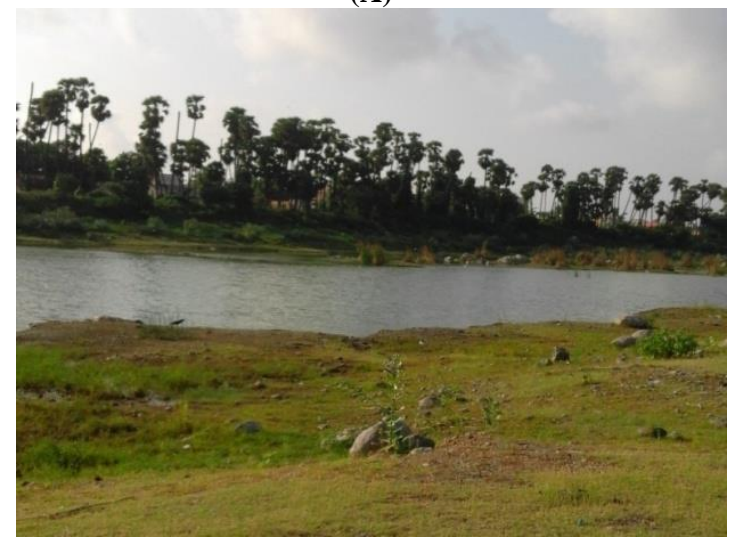

(B)

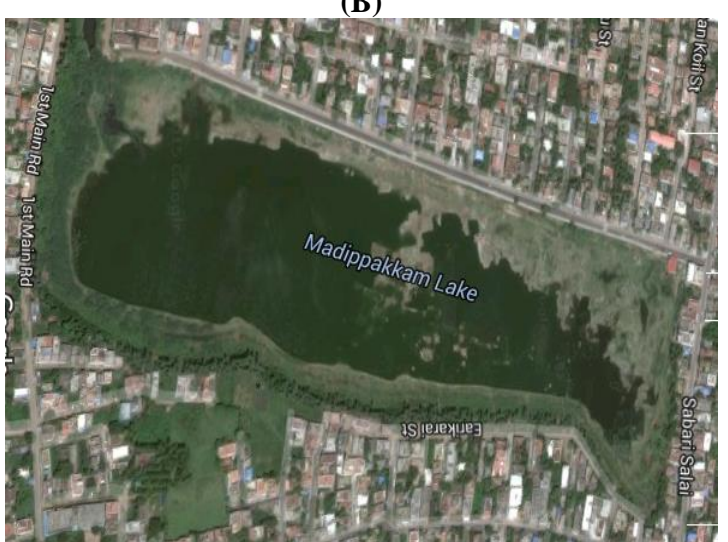

Fig. 1: Sampling Place of Madipakkam Lake (A), Satellite Image (B), Chennai, India.

\subsection{DNA extraction and PCR amplification}

The total DNA was extracted from the individual copepod using Qiagen Blood tissue kit. The 18S rDNA gene was amplified using two overlapping fragments. The first fragment was amplified using the forward primer LCO-1490(5'GGTCAACAAATCATAAAGATATTGG-3') AND HCO2198(5'-TAAACTTCAGGGTGACCAAAAAATCA-3') (Folmer et al. 1994). The polymerase chain reaction was performed under the following conditions: $25 \mathrm{pmol}$ each primer; $2.0 \mathrm{mM} \mathrm{MgCl} 2$; $1 \times$ PCR buffer; $2 \mathrm{mM}$ each dNTP; 2.5 units Taq DNA polymerase; and $2-5 \mu \mathrm{l}$ of DNA extract. The total volume of each PCR reaction was $50 \mu \mathrm{l}$. Thermal cycling was performed according to the following: $96^{\circ} \mathrm{C}$ for $5 \mathrm{~min}$.; $80^{\circ} \mathrm{C}$ while the Taq was added to the reactions; $94^{\circ} \mathrm{C}$ for $1 \mathrm{~min}$., $55^{\circ} \mathrm{C}$ for $2 \mathrm{~min}$., and $72^{\circ} \mathrm{C}$ for 3 minutes for 40 cycles; final extension $72^{\circ} \mathrm{C}$ for $8 \mathrm{~min}$. PCR products were loaded onto a $1 \%$ TAE agarose gel. Sequences were carried out an automated sequencer.

\subsection{Phylogenetic analyses}

D. sicilis RNA homology searches were performed using BLASTn 2.2.24 programs at NCBI and similarity sequences were retrieved for phylogenetic analysis. The DNA sequences of the $18 \mathrm{~S}$ rRNA of all taxa were aligned with ClustalW to create an initial dataset. Likelihood ratio test was performed for determination of substitution model of DNA evolution, and nitrogenous frequency was found out. The data set was analyzed by Distance method UPGMA method and Maximum Likelihood method (Swofford 1998) to resolve phylogenetic relations using Phylip
3.69. The distance method uses nucleotide sequences to compute distance matrix. The distance for each pair of species estimates the total branch length between the two species. ML was implemented to assess substitution basis. The UPGMA method constructs a tree by successive clustering using an average-linkage method of clustering.

\section{Results}

The nucleotide sequence of 1282 base pair region of $18 \mathrm{~S}$ rRNA was determined for D. sicilis. The similarity of sequences of D. sicilis was retrieved by BLASTn program and maximum identity and E-value was $76 \%$ and 0.00 , respectively. Lists of accession number and organisms are presented in Table 1. The PCR products of D.sicilis individuals showed $76 \%$ similarity with the partial nuclear small subunit $18 \mathrm{~S}$ rRNA gene region of other calanoid copepods.

Table 1: Information of Species of Analyzed in this Study.

\begin{tabular}{|c|c|}
\hline Accession Number & Description \\
\hline KM091949 & $\begin{array}{l}\text { Diaptomus sicilis, } 18 \mathrm{~S} \text { small subunit ribosomal } \\
\text { RNA gene, partial sequence }\end{array}$ \\
\hline JX945132.1 & $\begin{array}{l}\text { Diaptomus cyaneus, } 18 \mathrm{~S} \text { small subunit RNA gene, } \\
\text { partial sequence }\end{array}$ \\
\hline JX945124.1 & $\begin{array}{l}\text { Diaptomus kenitraensis, } 18 \mathrm{~S} \text { small subunit RNA } \\
\text { gene, partial sequence }\end{array}$ \\
\hline JX945133.1 & $\begin{array}{l}\text { Diaptomus mirus, } 18 \mathrm{~S} \text { small subunit RNA gene, } \\
\text { partial sequence }\end{array}$ \\
\hline JX945123.1 & $\begin{array}{l}\text { Diaptomus castor, } 18 \mathrm{~S} \text { small subunit RNA gene, } \\
\text { partial sequence }\end{array}$ \\
\hline HQ0087591 & $\begin{array}{l}\text { Mesocyclops pehpiensis, } 18 \mathrm{~S} \text { small subunit RNA } \\
\text { gene, partial sequence }\end{array}$ \\
\hline
\end{tabular}

The mean distance between $D$. mirus, D. cyaneus, D. kenitraensis, M. pehpeiensis when compared with that of D. sicilis was 3.22.

\subsection{Genetic distance}

Results were obtained for all $18 \mathrm{~S}$ rRNA sequence of D. sicilis when compared with selected out-groups in pairwise nucleotide distance analysis (Table 2). Identical results of 0.000 were seen in the comparisons between individual of $D$. sicilis $18 \mathrm{~S}$ rRNA.

A range in between 0.01-0.18 was observed for the pairwise nucleotide distances [Kimura 2-parameter] comparison of D.sicilis $18 \mathrm{~S}$ rRNA gene sequences with the 18S rRNA gene sequences of selected cylcopoid copepods out-group M.pehpeiensis. On the other hand, a huge pairwise nucleotide distance of $1.65-2.02$ was observed between copepods of the order Cyclopoida M. pehpeiensis (Table 2).

\subsection{Phylogenetic analysis}

The molecule based tree constructed using ML method illustrated that it forms one out group M. pehpeiensis. Substitution frequency of A-0.000, T/U-8.86, C-8.86-18.43 and G-0.00-7.96 was calculated between Calanoid species. The 18S rRNA sequences of D.sicilis and selected outgroups were used to create a gene tree using UPGMA method [Fig. 2]. The tree branched out into two main clusters according to different orders as expected withOrder Calanoida on one cluster while the rest of the copepods from the order Cyclopoida on other main clusters. The cyclopoid copepod out groups was resolved with a high bootstrap value of $76 \%$, thus differentiating D.sicilis as well. 


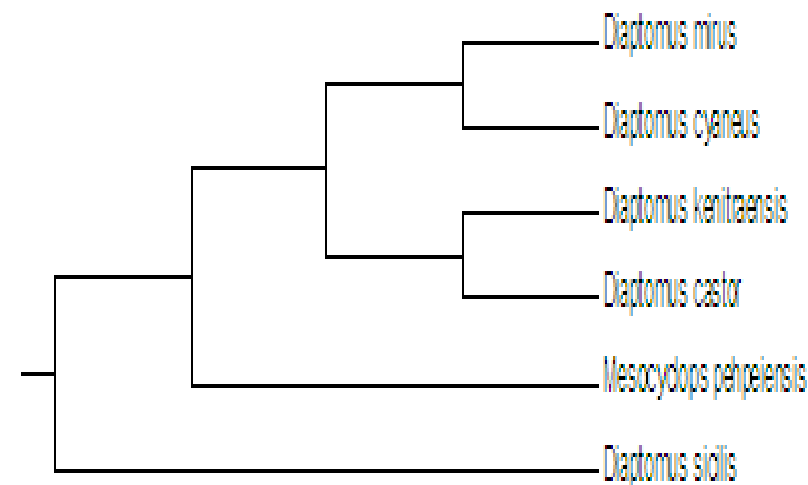

Fig. 2: Phylogeny Relationships of Calanoid Copepods on MolecularBased Analysis by UPGMA Method.

\section{Discussion}

The 18S rRNA gene proved to be effective for identifying the calanoid copepod upto species level (Shu et al. 2015). We found that $76 \%$ similarity between the species when to use the $18 \mathrm{~S}$ rRNA which is unfeasible when attempted to achieve a high rate of successful identification due to potential PCR or sequencing errors. The recovered $1282 \mathrm{bp}$ nuclear small subunit $18 \mathrm{~S}$ rRNA gene sequence, this study was in conformation with [23].This This conformation also reflects the ability and effectiveness of Universal Primers LCO-1490 and HCO-2198 described by Folmer et al. (1994) to target partial nuclear small subunit 18S rRNA region in most invertebrates, including copepods.

Table 2: Distance Matrix between Calanoid Copepods

\begin{tabular}{lllllll}
\hline Species & DS & DM & DC & DK & DC & MP \\
\hline Diaptomus sicilis $(D S)$ & 0.00 & & & & & \\
Diaptomus mirus $(D M)$ & 0.16 & & & & & \\
Diaptomus cyaneus $(D C)$ & 0.16 & 0 & & & & \\
Diaptomus kenitraensis $(D K)$ & 0.15 & 0 & 0.00 & & & \\
Diaptomus castor $(D C)$ & 0.18 & 0 & 0.01 & 0.00 & & \\
Mesocylops pehpeiensis & 1.65 & 1.92 & 1.93 & 2.01 & 2.02 & \\
$(M P)$ & & & & & & \\
\hline
\end{tabular}

The 18S rRNA sequences resolve relationships among genera but are not likely to resolve relationships within genera because of the overall slow rate of molecular evolution of ribosomal RNA genes (Hirai et al. 2015) which is reflected by generally low bootstrap values for species relationships within genera. Faster evolving molecules such as mitochondrial DNA genes are generally preferred for resolving such relationships.

This molecule proved to be the molecular markers for eukaryotes used in resolving generic and species-level relationships

(Sivakumar et al. 2013). To compare genetic distances within and among taxa used to determine whether a given group of calanoids have diverged on an average more or less than others. The divergence values among members of the calanoids were varying up to 2.02 substitutions per site (Table 2). The highest genetic distance between all calanoid taxa caused by extreme variation in M.pehpeiensis (0.01-0.18 substitution per site), which was more than twice as high as for the other order also for higherorderanalyses of copepod phylogeny (Lie et al. 2014). The lowest variation in Pairwise distance was between D.castor [0.000.01 substitutions per site] (Table 2). In Maximum likelihood method, the variation between species is 7.21-18.43 (Table 2).Thum (2004) claimed that $18 \mathrm{~S}$ rRNA could be used to evaluate the monophyly of recognized genera and their inter-relationships. Even rapidly-evolving mitochondrial genes often show support for deep notes. Cameron et al. (2004) reported that $18 \mathrm{~S}$ rRNA had the best phylogenetic signal ratio using Neighbour-joining tree. Mitochondrial Cytochrome Oxidase I (mtCOI) gene proved to be useful to resolve evolutionary relationships among closely related species for a wide range of taxa, especially for calanoid copepods and euphausiids (Bucklin 2011). In most of the species variation of mtCOI within a species is far less than variation between spe- cies making the gene as a diagnostic molecular systematic character. While intraspecific mtCOI sequence variation ranged from $0.5 \%$ to $2 \%$ and interspecific variation generally ranged from $10 \%$ to $20 \%$ (Bucklin 2011)

Based on molecular data the freshwater calanoid copepods showed different algorithms and similar types of topologies useful for designing molecular analyses using phylogeny tree construction. Present molecular studies on relationship of D. sicilis with other freshwater calanoid copepods indicate that this species is close to D.castor followed by D.keniraensis.

\section{Acknowledgement}

We thank DST AS (SR/SO-AS 28/2012dt11.1.2013) New Delhi for funding support to carry out this work.

\section{References}

[1] Aibin Zhan1, Song He1Emily A. Brown Fred eric J.J. Chain Thomas W. TherriaultCathryn L. Abbott Daniel D. Heath Melania E. Cristescu \& Hugh J. MacIsaac (2014) Reproducibility of pyro sequencing data for biodiversity assessment in complex communities. Methods in Ecology and Evolution 5(9): 881890.http://dx.doi.org/10.1111/2041-210X.12230.

[2] Anton S. Petrov, Chad R. Bernier, BurakGulen, Chris C. Waterbury, Eli Hershkovits, Chiaolong Hsiao, Stephen C. Harvey, Nicholas V. Hud, George E. Fox, Roger M. Wartell\& Loren Dean Williams (2014) Secondary Structures of Petrov rRNAs from All Three Domains of Life. PLOS One 9(2): 88222http://dx.doi.org/10.1371/journal.pone.0088222.

[3] Bucklin A \& Steinke D (2011).DNA barcoding of marine metazoan. Annual Review of Marine Science 3: 471508.http://dx.doi.org/10.1146/annurev-marine-120308-080950.

[4] Bucklin a (2011) Methods for population genetic analysis of zooplankton, Chapter 11 .In: the zooplankton methodology manual, International Council for the Exploration of the Sea, Academic. London, 533-570.

[5] Cameron SL, Miller KB, Haese CA Whiting MF \& Barker SC (2004) Mitochondrial genome data alone are not enough to unambiguously resolv the relationships of Entognatha. Insecta and Crustacea sensulato (Arthropoda) 20:534-557.

[6] Dupuis JR, Roe AD \& Sperling FAH (2012) Multilocus species delimitation in closely related animals and fungi: one marker is not enough. Molecular Ecology 21(18): 44224436.http://dx.doi.org/10.1111/j.1365-294X.2012.05642.x.

[7] Folmer O, Black M, Hoeh W, Lutz R \&Vrijenhoek R(1994) DNA primers for amplification of mitochondrial cytochrome c oxidase subunit I from diverse metazoan invertebrates. Molecular Marine Biology and Biotechnology 3: 294-299.

[8] Fonseca VG, Carvalho GR \& Nichols B (2014) Metagenetic analysis of patterns of distribution and diversity of marine meiobenthic eukaryotes. Global Ecology and Biogeographic Letters 23(11): 12931302.http://dx.doi.org/10.1111/geb.12223.

[9] Hirai J, Kuriyama M, Ichikawa T, Hidaka K \&Tsuda A (2015) A metagenetic approach for revealing community structure of marine planktonic copepods. Molecular Ecology Resources 15: 6880.http://dx.doi.org/10.1111/1755-0998.12294.

[10] Ho Young Soh, Sun Woo Kwon, Woncheol lee \&Yang Ho Yoon (2012) A new Pseudo diaptomus (copepod, Calanoida) from Korea supported by Molecular data. Zoo taxa 3368: 229-244.

[11] HumesAG (1994) How many copepods? Hydrobiology 292-293: 1 7.http://dx.doi.org/10.1007/BF00229916.

[12] Huys R \& Llewellyn-Hughes J (2007) extraordinary host switching in siphon stomatoid copepods and the demise of the monstrilloida: integrating molecular data, ontogeny and antennulary morphology. Molecular Phylogeny and Evolution43: 368378.http://dx.doi.org/10.1016/j.ympev.2007.02.004

[13] Kanchon K, Dasmahapatra, Marianne Elias, RyanI,Hill, Joseph I \& Hoffman S (2010) Mitochondrial DNA barcoding detects some species that are real and some that are not. Molecular Ecology Resources 10: 264-273.http://dx.doi.org/10.1111/j.1755-0998.2009.02763.x.

[14] Kruger M, Kruger C, Walker C, Stockinger H\&Schussler A(2012) Phylogenetic reference data for systematic and phylo taxonomy of arbuscular mycorrhizal fungi from phylum to species level. New Phytologist 193(4): 970-984. http://dx.doi.org/10.1111/j.14698137.2011.03962.x. 
[15] Lie AAY, Liu ZF, Hu SK, Jones AC, Kim DY, Peter D, Countway, Linda Amaral A, Zettler, Craig CaryS, Evelyn SherrB, Barry F.Sherr, Rebecca J.Gast and David \&Caron A ( 2014) Investigating Microbial Eukaryotic Diversity from a Global Census: Insights from a Comparison of Pyrotag and Full-Length Sequences of 18S rRNA Genes. Applied and Environmental Microbiology 80(14): 43634373.http://dx.doi.org/10.1128/AEM.00057-14.

[16] Ranga Reddy Y (1994) Copepoda: Calanoida: Diaptomidae. Key to the genera Heliodiaptomus, Allodiaptomus, Neodiaptomus, Phyllodiaptomus, Eodiaptomus, Arctodiaptomus and Sinodiaptomus, SPB Acad Pub, The Hague, Netherland:

[17] Shu Wu, JieXiong\&Yuhe Yu (2015) Taxonomic Resolutions Based on 18S rRNA Genes: A Case Study of Subclass Copepoda. PLOS ONE DOI: 10.1371.http://dx.doi.org/10.1371/journal.pone.0131498.

[18] Sivakumar R, Anandan M, Muthupriya P, Gopikrishna M \& Altaff K (2013) PhylogeneticAnalysis of Thermocyclops decipiens with Reference to $18 \mathrm{~S}$ rDNA. Indian Journal of Science and Technology 6:5585-5592.

[19] Stoeckle MY \& Hebert PDN (2008) Barcode of life: DNA tags help classify life. Scientific American 299: 82 88.http://dx.doi.org/10.1038/scientificamerican1008-82.

[20] Swofford DL, PAUP* (1998) Phylogenetic analysis using parsimony (*and other methods), 232 version 4.Sinauer, Sunderland, Mass.

[21] Tang CQ, Leasi F. Obertegger U. Alexander Kieneked\&Barraclough TG(2012) Diego Fontaneto. The widely used small subunit $18 \mathrm{~S}$ rDNA molecule greatly underestimates true diversity in biodiversity surveys of the meiofauna. Proceedings of the Nattional Academy of the Science USA Oct 2; 109(40): 16208-16212.

[22] Thum R\& Harrison RG (2009) Deep genetic divergences among morphologically similar and parapatric Skistodiaptomus (Copepoda: Calanoida: Diaptomidae) challenge the hypothesis ofPleistocene speciation. Biological Journal of the Linnean Society 96.http://dx.doi.org/10.1111/j.1095-8312.2008.01105.x.

[23] Thum RA \& DerryAM (2008) Taxonomic implications for diaptomid copepods based on contrasting patterns of mitochondrial DNA sequence divergences in four morpho species. Hydrobiologia 614: 197207.http://dx.doi.org/10.1007/s10750-008-9506-x.

[24] Thum RA (2004) Using 18S rDNA to resolve diaptomid copepod (Copepoda: Calanoida: Diaptomidae) phylogeny: an example with the North American genera. Hydrobiologia 519: 135141.http://dx.doi.org/10.1023/B:HYDR.0000026500.27949.e9.

[25] Wyngaard GA, Hołynska M \& James A (2010) Schulte II. Phylogeny of the freshwater copepod Mesocyclops (Crustacea: Cyclopidae) based on combined molecular and morphological data, with notes on biogeography. Molecular Phylogenetics and Evolution 55:753764.http://dx.doi.org/10.1016/j.ympev.2010.02.029. 